\title{
FACTORS IMPORTANT FOR ACHIEVING THE \\ COMPETITIVENESS OF INDUSTRIAL AND AGROINDUSTRIAL PRODUCTS
}

\author{
Nikola Ćrčićl ${ }^{1}$ Vuk Miletić ${ }^{2}$ \\ *Corresponding author E-mail: nikolavcurcic@yahoo.com
}

\begin{tabular}{l} 
A R T I C L E I N F O \\
Original Article \\
Received: 14 June 2020 \\
Accepted: 25 July 2020 \\
doi:10.5937/ekoPolj2003831C \\
UDC 339.13:631.57 \\
\hline
\end{tabular}

Keywords:

competitiveness factors, product quality, market, business improvement

JEL: L11, D24, M20

\begin{abstract}
A B S T R A C T
The subject of research in this paper is the business success of an organization aimed at assessing selected factors relevant to creating sustainable competitiveness of industrial and agroindustrial products in the target market. The research was conducted on the basis of a specially designed questionnaire on a sample of one hundred organizations operating on the territory of Serbia. The premise is that the factors that affect the competitiveness of industrial and agroindustrial products of different organizations have different effects on the results of their business activities and the perception of their importance for improving the quality of business. Numerous factors determine the level of competitiveness of products of organizations, which imposes the need for the evaluation and adaptation of the existing business concept to the arising changes. Namely, relevant analyses show that national organizations cannot be competitive if they do not meet the key requirement - the production of quality products in accordance with the standards of the modern world market, as indicators of the current situation show. The methods used in this research are the hypotheticaldeductive, the analytical-deductive and the comparative method, the historical and the statistical-descriptive method, and the method of comparative statistics (ch2 test, ANOVA). The results of the research show that the key factors for increasing the level of competitiveness of industrial and agroindustrial products of domestic organizations are competitive price, good design, high functionality, fast service, quality marketing, etc.
\end{abstract}

(C) 2020 EA. All rights reserved.

1 Nikola Ćurčić, Ph.D., Research Associate, Institute of Agricultural Economics, Volgina 15, 11070 Belgrade, Phone: +381 6427777 71, E-mail: nikolavcurcic@yahoo.com, ORCID ID (https://orcid.org/0000-0003-3375-2690)

2 Vuk Miletić, Ph.D., Assistant Professor, College of Academic Study “Dositej”, Bulevar Vojvode Putnika 7, 11000 Belgrade, Phone: +381 6005201 54, E-mail: vukmiletic@gmail.com, ORCID ID (https://orcid.org/0000-0002-6250-6803) 


\section{Introduction}

Competitiveness is a key prerequisite for the business success of any modern organization (Ćurčić, 2018). It involves the ability of an organization to produce goods and services that meet international market criteria. At the same time, competitiveness reflects a high and sustainable level of revenue. Organizations on the market should offer modern, quality and cheap products, quality servicing, modern design, etc. In this sense, organizations are forced to continuously increase business efficiency, to innovate the organization (Pascu, Lieshout, 2009) and the industrial and agroindustrial products, to improve management and employees, to entrepreneurially shape and use new opportunities, to protect the environment, etc. In this way, organizations need to increase their competitiveness and enable their own survival, growth and development in an international environment.

Certainly, there are successful strategies to increase the competitiveness of industrial and agroindustrial products. They are associated with generating quality products, with high marketing costs, with the cost of introducing a new product to the market (Porter, 1980), etc. Competitive strategy of the competitiveness of products, in addition to marketing, includes other functions and considerations, such as in what kind of markets the organization should compete with rivals, with what kind of goals and marketing programs. That is why it is important to continuously review the factors that are important for achieving the competitiveness of industrial and agroindustrial (Marković, Krstić, Rađenović, 2019) products. Organizations working in the same or similar environments can compete using a variety of competitive methods (Namiki, 2011) thanks to the dissimilar strategic orientations of their management and other internal specific capabilities. It is also striking that organizations of different sizes operating at different levels with the ability to innovate products primarily in hightech industries generally have better performance (Worley et al. 2014) than others. Therefore, managers of innovative organizations should focus on a strategy of success - targeting consumers who are constantly changing their needs for perceived industrial and agroindustrial products or a quick response to their service requirements.

An organization can create and deliver more value to a customer/consumer by offering lower prices for the same or similar product, or it can offer more benefits to customers, which justify higher prices of products (Kotler, Vong, Sonders, Armstrong, 2007). Organizations that emphasize low prices in the function of achieving competitiveness primarily have two alternatives at their disposal. One is to target consumers looking for affordable prices for industrial and agroindustrial products with a special need for short delivery time, and the other is to serve customers in niche markets who are looking for affordable prices. The decision on which market segment to focus depends on the competence of the organization and the available resources (Vukajlović, Curčić, 2016). 


\section{Quality product - the basis of long-term business success of an organization}

The path to the competitiveness of an organization is expressed through the quality of its products. Poor quality, small number of products adapted to new international standards, limited series, unattractive design and packaging, outdated technology and high product prices are the main reasons why Serbian products cannot compete with the products of global market leaders, but also with companies coming from newly industrialized countries (Miletić, Ćurčić, Aničić, 2017). In order to achieve business success in both domestic and international markets, organizations face the challenge of creating a competitive product/service. Today, the customer/consumer expects exceptional quality of products (Končar, et al., 2019), i.e. the fulfillment of all their needs and desires, and at the same time they are ready to pay only the price that is more affordable than the competition's. The characteristics that determine the quality of products are the basic competitive instrument for differentiating a particular manufacturer from the products of its competitors.

Creating a competitive industrial product is one of the most important tasks of an organization that participates in shaping a given offer (Grubor, Milićević, Đokić, 2018). Taking into account the constant changes in the needs of market demand, it is necessary to offer a product/service which will have added value for the customer/consumer. That is why it is important that the organization knows the consumers (Miletć, Miletić, Ćurčić, 2018) to whom it places products and to take care of satisfied consumers because the success of business is based on it. Loyal customers/consumers, which will be dedicated to a particular product or brand of product, should be obtained and kept (Yeung, Ramasamy, 2007). Only the best survive on the market, not the biggest. Therefore, the organization must strive to offer consumers a product that will have the best possible market properties, because in this way the product gains in value. A quality product must have properties that put it in a special place when it comes to the beneficial effects for the customer, which is why it is necessary to continuously check the level of quality of business excellence and the performance and attitudes of users (Jelić, 2016).

If the management of the organization notices that there is a problem with lower sales of its industrial and agroindustrial products, it must start managing organizational changes of products. An organization can see such an impact the moment consumers stop being interested in its product. The reason for cosumers no longer buying the product may be poor quality, high price, poor design, inferior packaging or poor service. It is important that the company, institutional support (Simonović, Petrović, Ćurčić, 2019) has a well-organized product policy that will take care of the continuous process of their innovation. Policy is important for the growth (Walas-Trębacz, 2018), development and performance of the organization because it is concerned with the development of a new product, redesign of the product, marketing and product placement.

The development of creative (Kokeza, 2016) competitive products in the process of identifying market requirements and needs has a special place. It is based on a 
systematic analysis of the needs of current and potential customers in order to design a product/service that best meets their expectations. The development of competitive products implies not only the ability to design something successfully (Chang, 2012), but also the ability to successfully produce the designed product in accordance with the idea and standards of high quality and rational use of available resources (Mullins et al., 2008). In the process of shaping an idea into a product, the tolerance of uncertainty is an acceptable characteristic and it is an important factor of competitiveness (Maričić, Djordjević, 2015). The purpose of design in this process is the realization of an idea that is most often caused by the need to solve a particular problem of customers/consumers.

The product, i.e. the value (Haavisto, 2014) that arises in response to the articulated needs of consumers should ensure the long-term business success of the organization, especially in increasingly competitive markets.

What is decisive today is the fact that knowledge becomes a product, and corporate intellectual property is more valuable than physical resources. Not only must a modern organization continuously create knowledge, but it must also increase value (Brenson, 2010).

\section{Research methodology}

The research for the purpose of rating selected factors of importance for creating sustainable competitiveness of industrial and agroindustrial products of a national organization was realized as an empirical transversal study. The premise of the research is: Factors that affect the competitiveness of products of different organizations have a different impact on the results of their business activities and the perception of their importance for improving business performance.

The research was conducted on the basis of a specially prepared questionnaire on a sample consisting of 96 organizations operating in Serbia, out of which $42.7 \%$ were micro organizations, $25 \%$ were small organizations, $15.6 \%$ were medium-sized organizations, while the percentage of large organizations was $16.7 \%$. Of the observed organizations in the sample, $18.8 \%$ operate at the local level, $22.9 \%$ at the national level, $26 \%$ at the regional level, while $32.3 \%$ of organizations operate at the international level. The largest number of organizations exist for more than 15 years $(38.5 \%)$, the percentage of organizations operating from $8-15$ years is $31.3 \%$, organizations operating from 4-7 years take up $19.8 \%$ of the sample, while the smallest percentage of organizations have been operating up to 3 years (19.4\%). Most organizations perform service-based activities $(61.5 \%)$, followed by organizations that perform both service and manufacturing activities (22.9\%), and the fewest are those with exclusively manufacturing activities (15.6\%).

The purpose of the questionnaire was to collect primary information about the factual situation in the national business environment, i.e. to assess the factors of importance for achieving competitiveness of industrial and agroindustrial products of the organization. The factors important for achieving a competitive position were evaluated by respondents with grades from 1 to 5 , where each factor was evaluated in relation to 
their level of significance (1 - the least important among the abovementioned factors, 5 - the most important factor).

The hypothetical-deductive method, the analytical-deductive method, the comparative method, the historical and statistical descriptive method, and the method of comparative statistics (ch2 test, ANOVA) were used in the paper.

\section{Research results}

Considering the assessments of factors important for achieving competitiveness of industrial and agroindustrial products of the organization, the survey results show that half of the organizations in the sample $(50 \%)$ rated the importance of competitive price as a factor important for the competitiveness of their organization's products with grade $5.19 .8 \%$ rated the price with a rating of $3 ; 17.7 \%$ of organizations rated the price as a factor of importance for the competitiveness of products/services with a score of 4; the lowest score of 1 was given by $7.3 \%$ of organizations, and grade 2 was given by $5.2 \%$ of organizations. Absolute values of price ratings as a factor of importance for the competitiveness of products are given in Figure 1.

Figure 1. Absolute values of the ratings of price as a factor of importance for the competitiveness of products of an organization

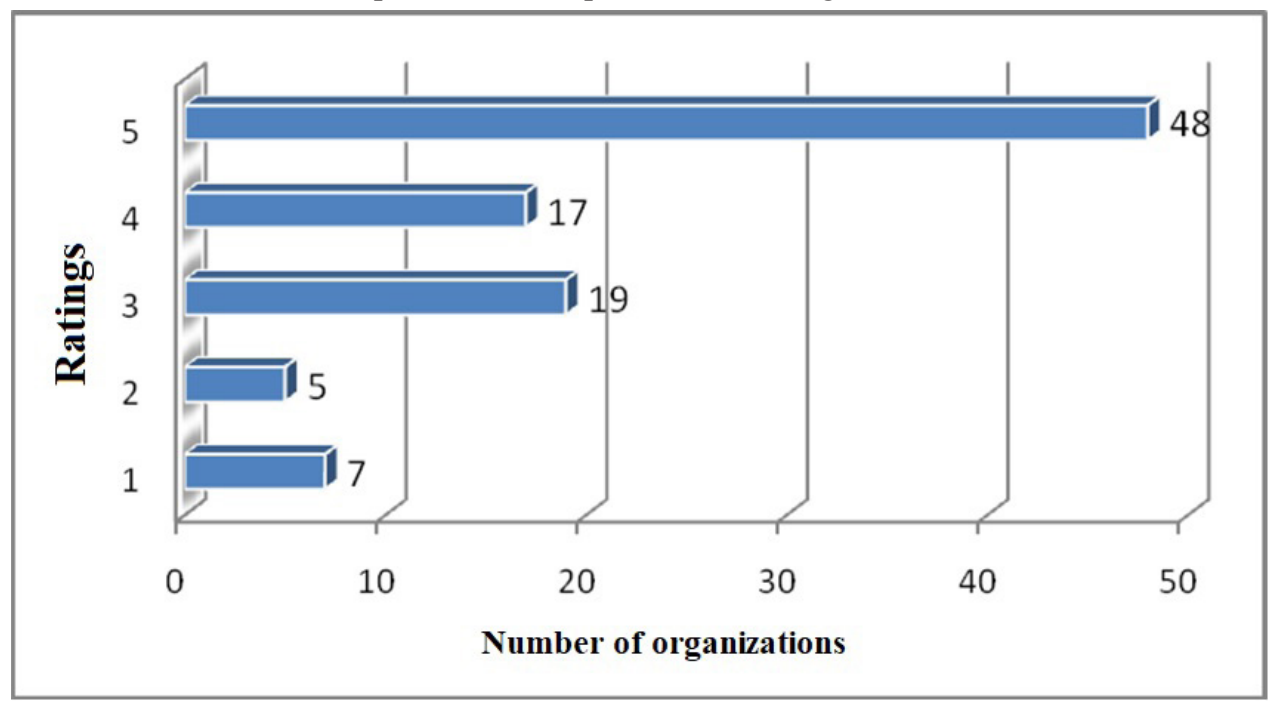

Source: Ćurčić, 2018

Good design as a factor of importance for the competitiveness of products was rated by the highest percentage of organizations $(27.1 \%)$ with the lowest score of 1 ; grade 2 was given by $22.9 \%$ of organizations; grade 3 was given by $17.7 \%$ of organizations; grade 4 was given by $24 \%$ of organizations, while the highest score of 5 was given by $8.3 \%$ of organizations. Absolute values of the ratings are presented in Figure 2. 
Figure 2. Absolute values of the ratings of good design as a factor of importance for the competitiveness of an organization's products

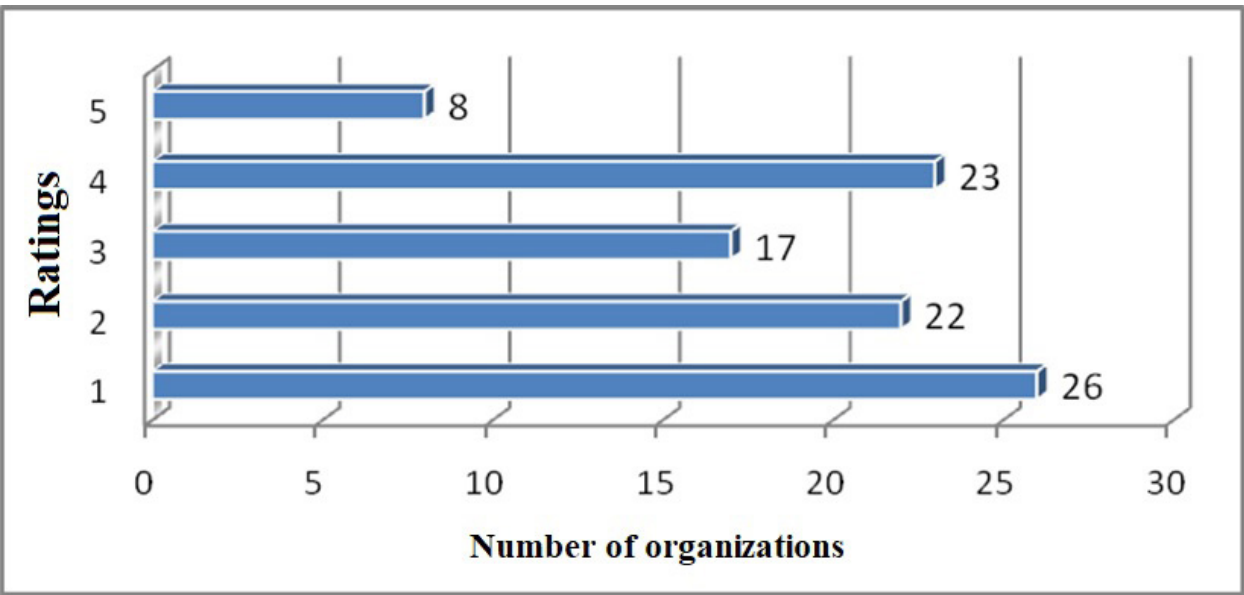

Source: Ibidem, 145

Good functionality as a factor of importance for the competitiveness of products was rated by the highest percentage of organizations $(36.5 \%)$ with grade 3 , grade 4 was given by $21.9 \%$ of organizations, grade 2 was given by $20.8 \%$ of organizations, the highest grade 5 was given by $12.5 \%$ of organizations, while the lowest grade 1 was given by $8.3 \%$ of organizations. Absolute values of the ratings of good functionality as a factor of importance for the competitiveness of products of the organization are presented in Figure 3.

Figure 3. Absolute values of the ratings of good functionality as a factor of importance for the competitiveness of an organization's products

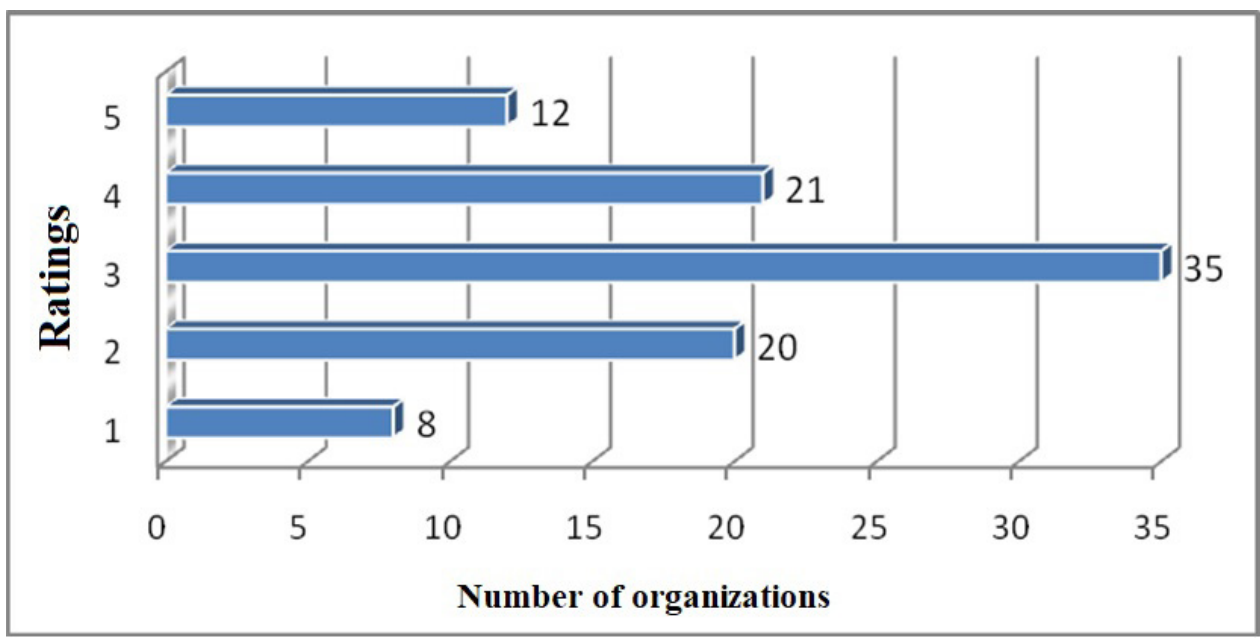

Source: Ibidem

The largest percentage of organizations (39.6\%) rated fast service as a factor of importance for the competitiveness of products of the organization with the lowest 
grade 1, grade 2 was given by $27.1 \%$ of organizations, grade 3 was given by $11.5 \%$ of organizations, $16.7 \%$ of organizations gave the rating of 4 , while the highest score of 5 was given by $5.2 \%$ of organizations. Absolute values of the ratings of fast service as a factor of importance for the competitiveness of products are presented in Figure 4.

Figure 4. Absolute values of the ratings of fast service as a factor of importance for the competitiveness of an organization's products

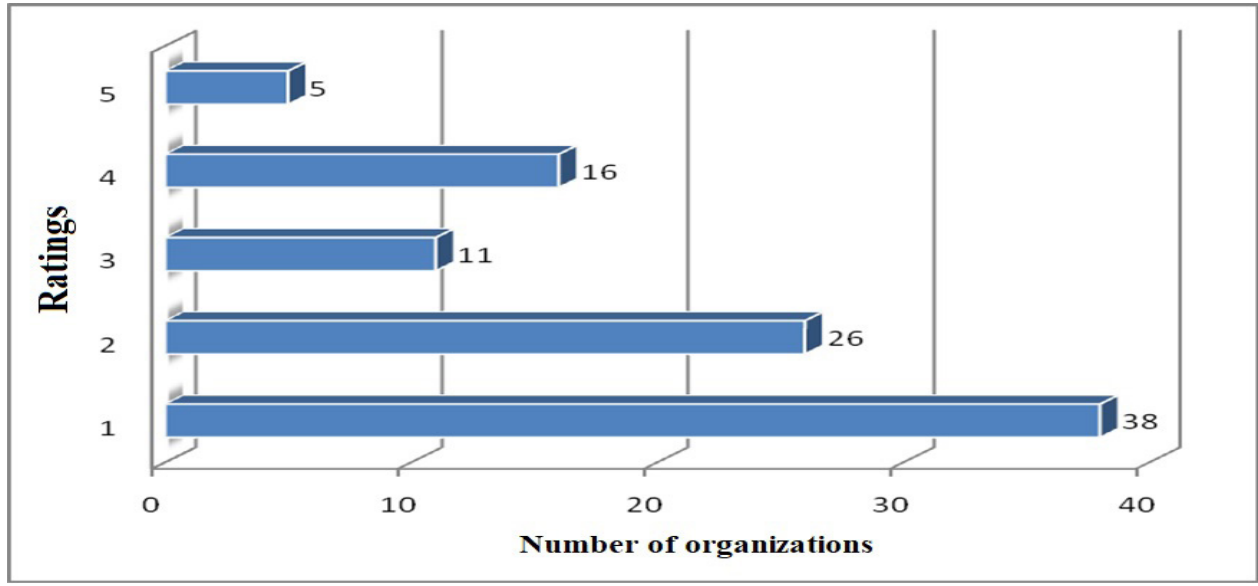

Source: Ibidem, 146

The highest percentage of organizations (24\%) rated good marketing as a factor of importance for the competitiveness of products with the highest score of 5, grade 4 was given by $19.8 \%$ of organizations, grade 3 was given by $14.6 \%$ of organizations, grade 2 was given by $22.9 \%$ of organizations, while the lowest grade 1 was given by $18.8 \%$ of organizations. Absolute values of the ratings of marketing as a factor of importance for the competitiveness of products are presented in Figure 5.

Figure 5. Absolute values of the ratings of markerting as a factor of importance for the competitiveness of an organization's products

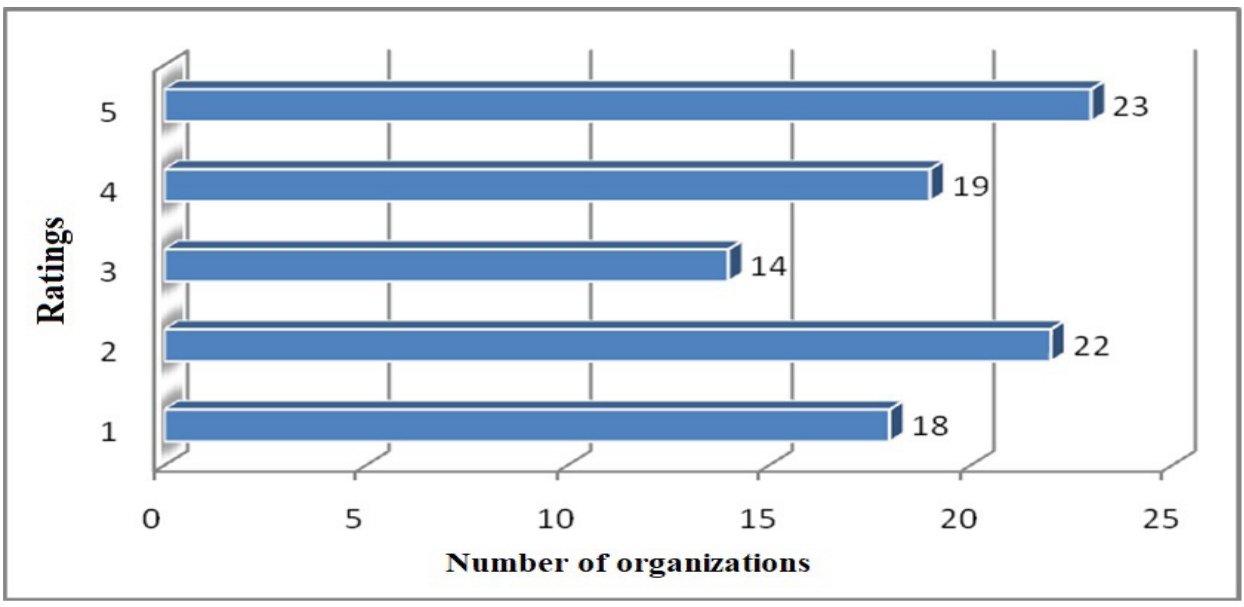

Source: Ibidem, 147 
Table 1 presents the mean values of assessments of the importance of factors for the competitiveness of products of the organization. From the table it can be seen that the most important factor in the competitiveness of products/services is the price with an average rating of 3.98, followed by good marketing with an average rating of 3.07 , then good functionality (3.09), good design (2.64), and the least significant was fast service which was rated with an average score of 2.21 .

Table 1. Mean values of the ratings of factors relevant to the competitiveness of products of an organization

\begin{tabular}{|l|l|l|l|l|l|}
\hline & Competitive price & $\begin{array}{c}\text { Good } \\
\text { design }\end{array}$ & Good functionality & $\begin{array}{c}\text { Fast } \\
\text { service }\end{array}$ & Good marketing \\
\hline Mean values & 3.98 & 2.64 & 3.09 & 2.21 & 3.07 \\
\hline
\end{tabular}

Source: Ibidem

Figure 6 presents the percentage of individual factors important for achieving competitiveness of products of an organization. It can be concluded that the highest number of organizations (50\%) gave the highest grade 5 (the most significant factor), while the least significant factor was rated 1 by $39.6 \%$ of organizations. It can be seen that good functionality received the rating of 3 from the highest percentage of organizations $(36.5 \%)$.

Figure 6. Percentage share of the ratings of the importance of factors for achieving competitiveness of products of an organization

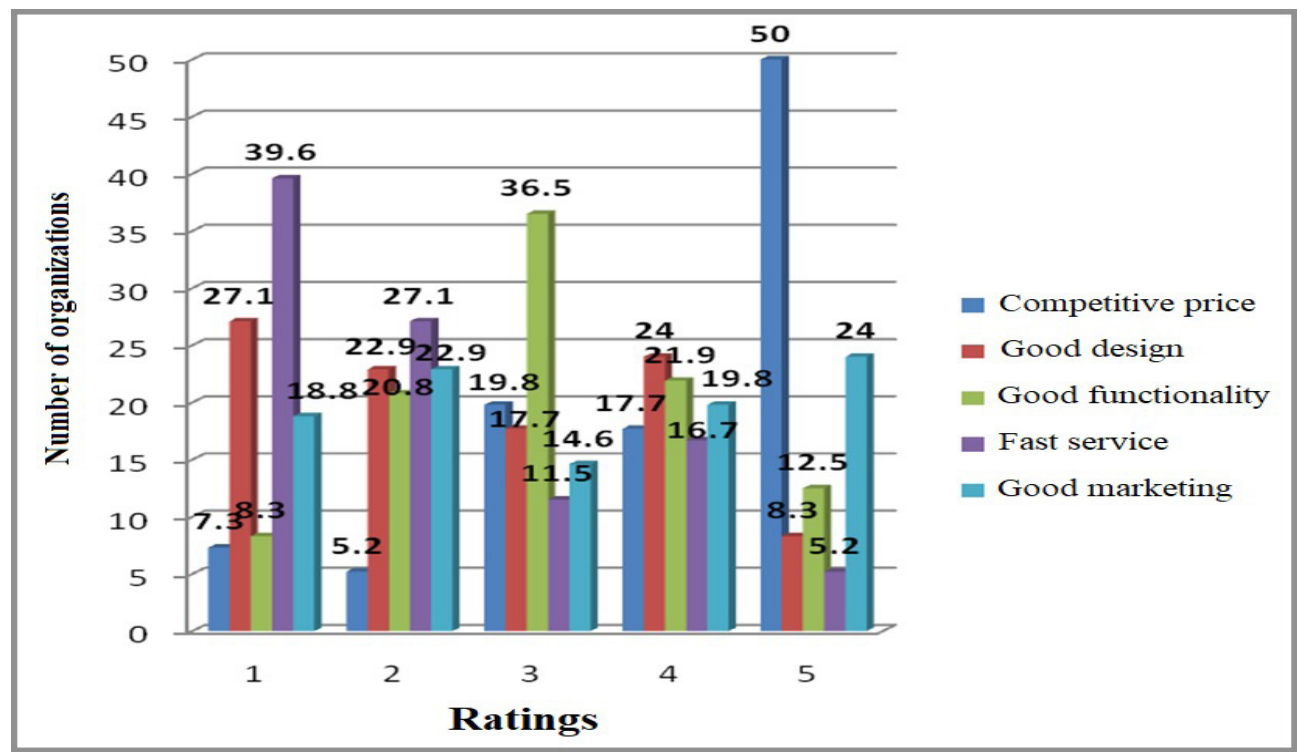

Source: Ibidem, 148

Factors important for achieving competitiveness of products of organizations were analyzed using the ANOVA test with a significance level of 0.05 (there is a statistically significant difference for the values of Sig $\leq 0.05$ ). A subsequent Tukey test determined among which organizations there is a particular difference in ratings. 
Thus, from Table 2, we can see the differences in the ratings of factors important for achieving competitiveness of products of an organization that differ in organizations of different sizes (micro, small, medium and large): 1) Significance of product quality and after-sales service for product competitiveness ( $\mathrm{Sig}=0.012<0.05)$; 2) Competitiveness of products of the organization in relation to domestic ones $(\mathrm{Sig}=0.024<0.05) ; 3$ ) Education of management/employees in the field of creating opportunities for the competitiveness of products $(\mathrm{Sig}=0.019<0.05)$.

Table 2. Differences in ratings of competitiveness factors of products of organizations of different sizes

\begin{tabular}{|c|c|c|c|c|c|c|}
\hline & & $\begin{array}{c}\text { Sum of } \\
\text { Squares }\end{array}$ & df & $\begin{array}{c}\text { Mean } \\
\text { Square }\end{array}$ & F & Sig. \\
\hline \multirow{3}{*}{$\begin{array}{l}\text { Significance of price for } \\
\text { product competitiveness }\end{array}$} & \begin{tabular}{|l|} 
Between \\
Groups
\end{tabular} & 2.399 & 3 & .800 & 1.557 & .205 \\
\hline & \begin{tabular}{|l|} 
Within \\
Groups
\end{tabular} & 47.258 & 92 & .514 & & \\
\hline & Total & 49.656 & 95 & & & \\
\hline \multirow{3}{*}{$\begin{array}{l}\text { Significance of product quality } \\
\text { and after-sales service for the } \\
\text { competitiveness of products }\end{array}$} & \begin{tabular}{|l|} 
Between \\
Groups \\
\end{tabular} & 10.782 & 3 & 3.594 & 3.882 & $.012 *$ \\
\hline & \begin{tabular}{|l} 
Within \\
Groups \\
\end{tabular} & 85.176 & 92 & .926 & & \\
\hline & Total & 95.958 & 95 & & & \\
\hline \multirow{3}{*}{$\begin{array}{l}\text { Competitiveness of your } \\
\text { products in relation to } \\
\text { domestic ones }\end{array}$} & $\begin{array}{l}\text { Between } \\
\text { Groups }\end{array}$ & 9.113 & 3 & 3.038 & 3.294 & $.024 *$ \\
\hline & $\begin{array}{l}\text { Within } \\
\text { Groups }\end{array}$ & 84.845 & 92 & .922 & & \\
\hline & Total & 93.958 & 95 & & & \\
\hline \multirow{3}{*}{$\begin{array}{l}\text { Competitiveness of your } \\
\text { products in relation to foreign } \\
\text { ones }\end{array}$} & \begin{tabular}{|l|} 
Between \\
Groups \\
\end{tabular} & 4.536 & 3 & 1.512 & 1.118 & .346 \\
\hline & \begin{tabular}{|l|} 
Within \\
Groups \\
\end{tabular} & 124.422 & 92 & 1.352 & & \\
\hline & Total & 128.958 & 95 & & & \\
\hline \multirow{3}{*}{$\begin{array}{l}\text { Marketing activities in your } \\
\text { organization directed at } \\
\text { increasing the competitiveness } \\
\text { of products }\end{array}$} & \begin{tabular}{|l|} 
Between \\
Groups \\
\end{tabular} & 1.205 & 3 & .402 & .336 & .800 \\
\hline & $\begin{array}{l}\text { Within } \\
\text { Groups } \\
\end{array}$ & 110.128 & 92 & 1.197 & & \\
\hline & \begin{tabular}{|l} 
Total \\
\end{tabular} & 111.333 & 95 & & & \\
\hline \multirow{3}{*}{$\begin{array}{l}\text { Level of state support in the } \\
\text { competitiveness of domestic } \\
\text { products }\end{array}$} & $\begin{array}{l}\text { Between } \\
\text { Groups }\end{array}$ & 1.875 & 3 & .625 & .443 & .723 \\
\hline & $\begin{array}{l}\text { Within } \\
\text { Groups }\end{array}$ & 129.750 & 92 & 1.410 & & \\
\hline & Total & 131.625 & 95 & & & \\
\hline
\end{tabular}

Source: Ibidem, 171

Table 3 presents the differences in the importance of product quality and after-sales service for the competitiveness of products of organizations of different sizes. It can 
be seen that a significant difference in ratings occurs in organizations that are small and large in size $(\mathrm{Sig}=0.021<0.05)$, as well as in organizations that are medium and large in size $(\mathrm{Sig}=0.019<0.05)$.

Table 3. Differences in ratings of the importance of product quality and after-sales service for the competitiveness of products of organizations of different sizes

Significance of product quality and after-sales service for the competitiveness of products

\begin{tabular}{|c|c|c|c|c|c|c|}
\hline \multirow[b]{2}{*}{$\begin{array}{l}\text { (I) Organization } \\
\text { size }\end{array}$} & \multirow{2}{*}{$\begin{array}{l}\text { (J) Organization } \\
\text { size }\end{array}$} & \multirow{2}{*}{$\begin{array}{c}\text { Mean } \\
\text { Difference } \\
\text { (I-J) }\end{array}$} & \multirow[b]{2}{*}{$\begin{array}{l}\text { Std. } \\
\text { Error }\end{array}$} & \multirow[b]{2}{*}{ Sig. } & \multicolumn{2}{|c|}{ 95\% Confidence } \\
\hline & & & & & $\begin{array}{l}\text { Lower } \\
\text { Bound }\end{array}$ & $\begin{array}{l}\text { Upper } \\
\text { Bound }\end{array}$ \\
\hline \multirow[t]{3}{*}{ Micro organization } & Small organization & -.319 & .247 & .571 & -.97 & .33 \\
\hline & $\begin{array}{l}\text { Medium } \\
\text { organization }\end{array}$ & -.436 & .290 & .441 & -1.20 & .32 \\
\hline & Large organization & .598 & .284 & .159 & -.14 & 1.34 \\
\hline \multirow[t]{3}{*}{ Small organization } & Micro organization & .319 & .247 & .571 & -.33 & .97 \\
\hline & $\begin{array}{l}\text { Medium } \\
\text { organization }\end{array}$ & -.117 & .317 & .983 & -.95 & .71 \\
\hline & Large organization & $.917(*)$ & .311 & .021 & .10 & 1.73 \\
\hline \multirow[t]{3}{*}{$\begin{array}{l}\text { Medium } \\
\text { organization }\end{array}$} & Micro organization & .436 & .290 & .441 & -.32 & 1.20 \\
\hline & Small organization & .117 & .317 & .983 & -.71 & .95 \\
\hline & Large organization & $1.033\left(^{*}\right)$ & .346 & .019 & .13 & 1.94 \\
\hline \multirow[t]{3}{*}{ Large organization } & Micro organization & -.598 & .284 & .159 & -1.34 & .14 \\
\hline & Small organization & $-.917(*)$ & .311 & .021 & -1.73 & -.10 \\
\hline & $\begin{array}{l}\text { Medium } \\
\text { organization }\end{array}$ & $-1.033(*)$ & .346 & .019 & -1.94 & -.13 \\
\hline
\end{tabular}

Source: Ibidem, 174

Table 4 shows that the competitiveness of products of an organization in relation to domestic ones differs in organizations of micro and small size $(\mathrm{Sig}=0.024<0.05)$.

Table 4. Difference in rating of the competitiveness of an organization's products in relation to domestic ones of different sizes

\begin{tabular}{|c|c|c|c|c|c|c|}
\hline \multicolumn{7}{|c|}{ Competitiveness of products of an organization in relation to domestic ones } \\
\hline \multirow{2}{*}{$\begin{array}{c}\text { (I) } \\
\text { Organization } \\
\text { size }\end{array}$} & \multirow{2}{*}{$\begin{array}{l}\text { (J) Organization } \\
\text { size }\end{array}$} & \multirow{2}{*}{$\begin{array}{c}\text { Mean } \\
\text { Difference } \\
\text { (I-J) }\end{array}$} & \multirow{2}{*}{$\begin{array}{l}\text { Std. } \\
\text { Error }\end{array}$} & \multirow[b]{2}{*}{ Sig. } & \multicolumn{2}{|c|}{ 95\% Confidence } \\
\hline & & & & & $\begin{array}{l}\text { Lower } \\
\text { Bound }\end{array}$ & $\begin{array}{c}\text { Upper } \\
\text { Bound }\end{array}$ \\
\hline \multirow[t]{3}{*}{$\begin{array}{l}\text { Micro } \\
\text { organization }\end{array}$} & Small organization & $-.713(*)$ & .247 & .024 & -1.36 & -.07 \\
\hline & Medium organization & -.263 & .290 & .800 & -1.02 & .49 \\
\hline & Large organization & -.588 & .283 & .168 & -1.33 & .15 \\
\hline \multirow[t]{3}{*}{$\begin{array}{l}\text { Small } \\
\text { organization }\end{array}$} & Micro organization & $.713(*)$ & .247 & .024 & .07 & 1.36 \\
\hline & Medium organization & .450 & .316 & .488 & \begin{tabular}{|l|}
-.38 \\
\end{tabular} & 1.28 \\
\hline & Large organization & .125 & .310 & .978 & \begin{tabular}{|l|}
-.69 \\
\end{tabular} & .94 \\
\hline
\end{tabular}


Competitiveness of products of an organization in relation to domestic ones

\begin{tabular}{|c|c|c|c|c|c|c|}
\hline \multirow{2}{*}{$\begin{array}{c}\text { (I) } \\
\text { Organization } \\
\text { size }\end{array}$} & \multirow[b]{2}{*}{$\begin{array}{l}\text { (J) Organization } \\
\text { size }\end{array}$} & \multirow{2}{*}{$\begin{array}{c}\text { Mean } \\
\text { Difference } \\
\text { (I-J) }\end{array}$} & \multirow[b]{2}{*}{$\begin{array}{l}\text { Std. } \\
\text { Error }\end{array}$} & \multirow[b]{2}{*}{ Sig. } & \multicolumn{2}{|c|}{ 95\% Confidence } \\
\hline & & & & & $\begin{array}{l}\text { Lower } \\
\text { Bound }\end{array}$ & $\begin{array}{l}\text { Upper } \\
\text { Bound }\end{array}$ \\
\hline \multirow[t]{3}{*}{$\begin{array}{l}\text { Medium } \\
\text { organization }\end{array}$} & Micro organization & .263 & .290 & .800 & -.49 & 1.02 \\
\hline & Small organization & -.450 & .316 & .488 & -1.28 & .38 \\
\hline & Large organization & -.325 & .345 & .783 & -1.23 & .58 \\
\hline \multirow[t]{3}{*}{$\begin{array}{l}\text { Large } \\
\text { organization }\end{array}$} & Micro organization & .588 & .283 & .168 & -.15 & 1.33 \\
\hline & Small organization & -.125 & .310 & .978 & -.94 & .69 \\
\hline & Medium organization & .325 & .345 & .783 & -.58 & 1.23 \\
\hline
\end{tabular}

Source: Ibidem, 175

Table 5 presents the differences in the ratings of the competitiveness of an organization's products in relation to foreign ones by observing organizations that operate at different levels of business. The results show that differences occur in organizations operating at the local and regional level ( $\mathrm{Sig}=0.013<0.05)$, as well as in organizations operating at the local and international level $(\mathrm{Sig}=0.008<0.05)$.

Table 5. Differences in ratings of product competitiveness of organizations in relation to foreign ones

\begin{tabular}{|c|c|c|c|c|c|c|}
\hline \multicolumn{7}{|c|}{ Competitiveness of your products in relation to foreign ones } \\
\hline \multirow{2}{*}{$\begin{array}{c}\text { (I) Level of } \\
\text { business of an } \\
\text { organization }\end{array}$} & \multirow{2}{*}{$\begin{array}{c}\text { (J) Level of } \\
\text { business of an } \\
\text { organization }\end{array}$} & \multirow{2}{*}{$\begin{array}{c}\text { Mean } \\
\text { Difference } \\
\text { (I-J) } \\
\end{array}$} & \multirow{2}{*}{$\begin{array}{l}\text { Std. } \\
\text { Error }\end{array}$} & \multirow[b]{2}{*}{ Sig. } & \multicolumn{2}{|c|}{ 95\% Confidence } \\
\hline & & & & & $\begin{array}{l}\text { Lower } \\
\text { Bound }\end{array}$ & $\begin{array}{l}\text { Upper } \\
\text { Bound } \\
\end{array}$ \\
\hline \multirow[t]{3}{*}{ Local level } & National level & -.263 & .346 & .873 & -1.17 & .64 \\
\hline & Regional level & $-1.044(*)$ & .337 & .013 & -1.93 & -.16 \\
\hline & International level & $-1.057(*)$ & .323 & .008 & -1.90 & -.21 \\
\hline \multirow[t]{3}{*}{ National level } & Local level & .263 & .346 & .873 & -.64 & 1.17 \\
\hline & Regional level & -.782 & .318 & .074 & -1.61 & .05 \\
\hline & International level & $-.795(*)$ & .304 & .050 & -1.59 & .00 \\
\hline \multirow[t]{3}{*}{ Regional level } & Local level & $1.044(*)$ & .337 & .013 & .16 & 1.93 \\
\hline & National level & .782 & .318 & .074 & -.05 & 1.61 \\
\hline & International level & -.013 & .293 & 1.000 & -.78 & .75 \\
\hline \multirow[t]{3}{*}{ International level } & Local level & $1.057(*)$ & .323 & .008 & .21 & 1.90 \\
\hline & National level & $.795(*)$ & .304 & .050 & .00 & 1.59 \\
\hline & Regional level & .013 & .293 & 1.000 & -.75 & .78 \\
\hline
\end{tabular}

Source: Ibidem, 181-182

Table 6 presents the differences in the ratings of the level of state support in the competitiveness of domestic products of organizations operating for different periods of time. It can be seen that there are differences between organizations that have operated from of 8 to 15 years and over 15 years $(\mathrm{Sig}=0.030<0.05)$. 
Table 6. Differences in ratings of the level of state support in the competitiveness of domestic products of organizations operating for different periods of time

Level of state support in the competitiveness of domestic products

\begin{tabular}{|c|c|c|c|c|c|c|}
\hline \multirow{2}{*}{$\begin{array}{c}\text { (I) Length of } \\
\text { business of an } \\
\text { organization }\end{array}$} & \multirow{2}{*}{$\begin{array}{l}\text { (J) Length of } \\
\text { business of an } \\
\text { organization }\end{array}$} & \multirow{2}{*}{$\begin{array}{c}\text { Mean } \\
\text { Difference } \\
\text { (I-J) }\end{array}$} & \multirow{2}{*}{$\begin{array}{l}\text { Std. } \\
\text { Error }\end{array}$} & \multirow[b]{2}{*}{ Sig. } & \multicolumn{2}{|c|}{ 95\% Confidence } \\
\hline & & & & & $\begin{array}{l}\text { Lower } \\
\text { Bound }\end{array}$ & $\begin{array}{l}\text { Upper } \\
\text { Bound }\end{array}$ \\
\hline \multirow[t]{3}{*}{ Up to 3 years } & From 4 to 7 years & .311 & .445 & .898 & -.86 & .08 \\
\hline & From 8 to 15 years & .400 & .416 & .772 & -.69 & -.04 \\
\hline & Over 15 years & -.386 & .406 & .777 & -1.45 & .01 \\
\hline \multirow[t]{3}{*}{ From 4 to 7 years } & \begin{tabular}{|l|} 
Up to 3 years \\
\end{tabular} & -.311 & .445 & .898 & -1.48 & 1.98 \\
\hline & From 8 to 15 years & .089 & .334 & .993 & -.79 & .85 \\
\hline & Over 15 years & -.697 & .322 & .141 & -1.54 & .90 \\
\hline \multirow[t]{3}{*}{$\begin{array}{l}\text { From } 8 \text { to } 15 \\
\text { years }\end{array}$} & Up to 3 years & -.400 & .416 & .772 & -1.49 & 2.04 \\
\hline & From 4 to 7 years & -.089 & .334 & .993 & -.96 & 1.04 \\
\hline & Over 15 years & $-.786\left(^{*}\right)$ & .280 & .030 & -1.52 & .96 \\
\hline \multirow[t]{3}{*}{ Over 15 years } & Up to 3 years & .386 & .406 & .777 & -.68 & 1.91 \\
\hline & From 4 to 7 years & .697 & .322 & .141 & -.15 & .90 \\
\hline & From 8 to 15 years & $.786(*)$ & .280 & .030 & .05 & .77 \\
\hline
\end{tabular}

Source: Ibidem, 188

Table 7 presents differences in the ratings of the level of state support in the competitiveness of domestic products in organizations engaged in different activities. The results show that differences occur in organizations that deal with service and those that deal with both service and manufacturing activities $(\mathrm{Sig}=0.041<0.05)$.

Table 7. Differences in ratings of the level of state support in the competitiveness of domestic products of organizations of different activities

\begin{tabular}{|c|c|c|c|c|c|c|}
\hline \multicolumn{7}{|c|}{ Level of state support in the competitiveness of domestic products } \\
\hline \multirow{2}{*}{$\begin{array}{c}\text { (I) } \\
\begin{array}{c}\text { Organization's } \\
\text { activity }\end{array}\end{array}$} & \multirow{2}{*}{$\begin{array}{c}\text { (J) Organization's } \\
\text { activity }\end{array}$} & \multirow{2}{*}{$\begin{array}{c}\text { Mean } \\
\text { Difference } \\
\text { (I-J) }\end{array}$} & \multirow[b]{2}{*}{$\begin{array}{l}\text { Std. } \\
\text { Error }\end{array}$} & \multirow[b]{2}{*}{ Sig. } & \multicolumn{2}{|c|}{ 95\% Confidence } \\
\hline & & & & & $\begin{array}{l}\text { Lower } \\
\text { Bound }\end{array}$ & $\begin{array}{l}\text { Upper } \\
\text { Bound }\end{array}$ \\
\hline \multirow[t]{2}{*}{ Service } & Manufacturing & .199 & .331 & .820 & -.59 & .99 \\
\hline & $\begin{array}{l}\text { Both service and } \\
\text { manufacturing }\end{array}$ & $-.704(*)$ & .286 & .041 & -1.38 & -.02 \\
\hline \multirow[t]{2}{*}{ Manufacturing } & Service & -.199 & .331 & .820 & -.99 & .59 \\
\hline & $\begin{array}{l}\text { Both service and } \\
\text { manufacturing }\end{array}$ & -.903 & .383 & .053 & -1.82 & .01 \\
\hline \multirow[t]{2}{*}{$\begin{array}{l}\text { Both } \\
\text { service and } \\
\text { manufacturing }\end{array}$} & Service & $.704(*)$ & .286 & .041 & .02 & 1.38 \\
\hline & Manufacturing & .903 & .383 & .053 & -.01 & 1.82 \\
\hline
\end{tabular}

Source: Ibidem, 193 


\section{Correlation analysis}

The aim of the correlation analysis was to describe the strength and direction of the relationship between two variables (organization size, business level and business length with factors relevant to raising the level of competitiveness of an organization's products). Pearson correlation coefficients (r) can have values from -1 to +1 . The sign indicates whether the correlations are positive (both variables decrease and increase together) or negative (one variable decreases while the other increases and vice versa). The absolute value of this coefficient (when the sign is ignored) shows the strength of the connection, namely (Cohen, 1998): small correlation $r=0.10$ to 0.29 ; medium correlation $r=0.30$ to 0.49 ; large correlation $r=0.50$ to 1.0 .

Table 8 presents the correlation of factors for achieving competitiveness of products (competitive price, good design, good functionality, fast service, good marketing) with the ratings of the competitiveness of organizations.

Table 8. Correlation of factors relevant to the competitiveness of products

\begin{tabular}{|c|c|c|c|c|c|c|}
\hline & & $\begin{array}{l}\text { Compe- } \\
\text { titive price }\end{array}$ & $\begin{array}{l}\text { Good } \\
\text { design }\end{array}$ & $\begin{array}{l}\text { Good } \\
\text { function- } \\
\text { ality }\end{array}$ & $\begin{array}{l}\text { Fast } \\
\text { service }\end{array}$ & $\begin{array}{l}\text { Good } \\
\text { marke- } \\
\text { ting }\end{array}$ \\
\hline \multirow{3}{*}{$\begin{array}{l}\text { Significance of price for } \\
\text { product competitiveness }\end{array}$} & $\begin{array}{l}\text { Pearson } \\
\text { Correla-tion }\end{array}$ & $.205(*)$ & -.175 & -.040 & .162 & -.133 \\
\hline & $\begin{array}{l}\text { Sig. } \\
(2 \text {-tailed) }\end{array}$ & .045 & .089 & .698 & .116 & .196 \\
\hline & $\mathrm{N}$ & 96 & 96 & 96 & 96 & 96 \\
\hline \multirow{3}{*}{$\begin{array}{l}\text { Importance of product } \\
\text { quality and after-sales } \\
\text { service for product } \\
\text { competitiveness }\end{array}$} & $\begin{array}{l}\text { Pearson } \\
\text { Correla-tion }\end{array}$ & -.164 & $-.204(*)$ & -.012 & $.215\left(^{*}\right)$ & .150 \\
\hline & $\begin{array}{l}\text { Sig. } \\
\text { (2-tailed) }\end{array}$ & .110 & .046 & .906 & .036 & .145 \\
\hline & $\mathrm{N}$ & 96 & 96 & 96 & 96 & 96 \\
\hline \multirow{3}{*}{$\begin{array}{l}\text { Competitiveness } \\
\text { of your products in } \\
\text { relation to domestic } \\
\text { ones }\end{array}$} & $\begin{array}{l}\text { Pearson } \\
\text { Correla-tion }\end{array}$ & .023 & -.072 & -.091 & $.232(*)$ & -.086 \\
\hline & $\begin{array}{l}\text { Sig. } \\
\text { (2-tailed) }\end{array}$ & .825 & .483 & .377 & .023 & .402 \\
\hline & $\mathrm{N}$ & 96 & 96 & 96 & 96 & 96 \\
\hline \multirow{3}{*}{$\begin{array}{l}\text { Competitiveness } \\
\text { of your products in } \\
\text { relation to foreign ones }\end{array}$} & $\begin{array}{l}\text { Pearson } \\
\text { Correla-tion }\end{array}$ & -.025 & -.149 & .048 & .088 & .039 \\
\hline & $\begin{array}{l}\text { Sig. } \\
\text { (2-tailed) }\end{array}$ & .805 & .147 & .644 & .393 & .703 \\
\hline & $\mathrm{N}$ & 96 & 96 & 96 & 96 & 96 \\
\hline \multirow{3}{*}{$\begin{array}{l}\text { Marketing activities } \\
\text { in your organization } \\
\text { directed at increasing } \\
\text { the competitiveness of } \\
\text { products }\end{array}$} & $\begin{array}{l}\text { Pearson } \\
\text { Correla-tion }\end{array}$ & .084 & $-.244(*)$ & $-.283(* *)$ & $.288(* *)$ & .126 \\
\hline & $\begin{array}{l}\text { Sig. } \\
\text { (2-tailed) }\end{array}$ & .417 & .017 & .005 & .004 & .219 \\
\hline & $\mathrm{N}$ & 96 & 96 & 96 & 96 & 96 \\
\hline
\end{tabular}




\begin{tabular}{|c|c|c|c|c|c|c|}
\hline & & $\begin{array}{l}\text { Compe- } \\
\text { titive price }\end{array}$ & $\begin{array}{l}\text { Good } \\
\text { design }\end{array}$ & $\begin{array}{l}\text { Good } \\
\text { function- } \\
\text { ality }\end{array}$ & $\begin{array}{l}\text { Fast } \\
\text { service }\end{array}$ & $\begin{array}{l}\text { Good } \\
\text { marke- } \\
\text { ting }\end{array}$ \\
\hline \multirow{3}{*}{$\begin{array}{l}\text { Education of } \\
\text { management/ } \\
\text { employees in the area } \\
\text { of possible market share } \\
\text { increase and creating } \\
\text { competitiveness of } \\
\text { products }\end{array}$} & \begin{tabular}{|l|} 
Pearson \\
Correla-tion \\
\end{tabular} & -.002 & -.154 & .020 & $.294(* *)$ & -.133 \\
\hline & \begin{tabular}{|l|} 
Sig. \\
(2-tailed) \\
\end{tabular} & .987 & .134 & .846 & .004 & .198 \\
\hline & $\mathrm{N}$ & 96 & 96 & 96 & 96 & 96 \\
\hline \multirow{3}{*}{$\begin{array}{l}\text { Level of state support } \\
\text { in the competitiveness } \\
\text { of domestic products }\end{array}$} & \begin{tabular}{|l|} 
Pearson \\
Correla-tion \\
\end{tabular} & -.106 & .008 & .011 & .118 & -.033 \\
\hline & \begin{tabular}{|l|} 
Sig. \\
(2-tailed) \\
\end{tabular} & .305 & .938 & .912 & .253 & .749 \\
\hline & $\mathrm{N}$ & 96 & 96 & 96 & 96 & 96 \\
\hline
\end{tabular}

* Correlation is significant at the 0.05 level (2-tailed).

** Correlation is significant at the 0.01 level (2-tailed).

Source: Ibidem, 198

The results show that there is a negative correlation of low strength between marketing activities in organizations directed at increasing the competitiveness of products and good functionality $(\mathrm{r}=-0.283)$, as well as a positive correlation of low strength between marketing activities and fast service $(r=0.288)$. The results suggest that increasing marketing activities in the organization directed at improving competitiveness reduces the importance of functionality, and it increases the importance of fast service as a factor important to improve the competitiveness of products in the organization. Also, there is a positive correlation of low strength between the education of management/ employees in the area of possible market share increase and fast service $(r=0.294)$. The results suggest that increasing the education of the management increases the importance of fast service as a factor of importance for the competitiveness of products.

\section{Discussion and conclusion}

The aim of the research was to identify factors important for achieving competitiveness of industrial and agroindustrial products of a national organization and to discover the differences in the ratings of the factors important for increasing the level of competitiveness of products of organizations of different sizes and activities in relation to both domestic and foreign industrial and agroindustrial products.

The results of the research show that the most important factor for the competitiveness of an organization's products is competitive price, followed by good functionality, effective marketing, functional design and finally fast service.

The importance of price for the competitiveness of products was rated with a mean value of 4.34 , i.e. almost half of the organizations rated the price with a score of 5 , so it is concluded that organizations consider the price to be extremely important for the competitiveness of products. 
The mean value of product and after-sales service quality ratings for product competitiveness is 4.15. Most organizations rated the importance of product and aftersales service quality for the competitiveness of products/services with a score of 5 , so based on the results, it can be seen that the quality was rated as important for the competitiveness of products.

It can be concluded that, in the organizations that participated in the sample, the most important factors for the competitiveness of their products (mean value over 4) were price and the quality of products and after-sales service.

The results show that marketing activities in the organization directed at increasing the competitiveness of products were rated with a mean value of 3.42. The largest number of organizations, 28, rated marketing activities with a score of 3 and 4 . It can be seen that marketing activities directed at increasing the competitiveness of products/services are rated slightly above average.

The competitiveness of the products of the surveyed organizations in relation to domestic ones was rated with a mean value of 3.85. The largest number of organizations rated the competitiveness of products with a score of 4 , so it is concluded that the competitiveness of products in relation to domestic ones was rated as significant.

The competitiveness of products in relation to foreign ones was rated with a mean value of 3.29. The highest percentage of organizations rated the competitiveness of products in relation to foreign products with grades 3 and 4, which is an average score.

It can be concluded that the competitiveness of an organization's agricultural and industrial products is higher nationally than internationally.

The level of business (local, national, regional and international) significantly affects the differences in the competitiveness of products, primarily functional design, fast service and good marketing are factors that differ in importance for the competitiveness of products.

The results of the research show that there is a lack of expected state support in creating the competitiveness of domestic industrial and agroindustrial products, i.e. the largest number of organizations rated state support with the lowest score of 1 , while the mean value of the score is 2.06 .

After researching the differences in the ratings of factors important for competitiveness, the results show that regardless of the size of the organization, activity and length of business, the assessments of factors important for the competitiveness of products of the organization do not differ. The level of business, on the other hand, significantly affects the differences in the competitiveness of an organization's products.

The results indicate that it is necessary to focus on increasing after-sales service and design rather than on price competitiveness. Also, the state must make greater efforts to create competitiveness for organizations and their products/services. 
It can be concluded that Serbian companies cannot be successful without fulfilling the most important condition, which is to offer quality products that meet the requirements of the international market. Even more so, since the quality, price, the technological and ecological level, and the required degree of safety are at the core of industrial and agroindustrial product competitiveness.

The practical implications of the paper are reflected in the fact that the management of organizations from the industrial and agro sector in the Republic of Serbia can focus their efforts on established factors and create their strategies so as to enable the improvement of the competitiveness of their products and/or services. Therefore, the results are especially important for defining a development strategy in all areas of the Serbian economy, especially in the agro-industry.

\section{Conflict of interests}

The authors declare no conflict of interest.

\section{References}

1. Brenson, R. (2010). Nothing is impossible, Plato, Belgrade.

2. Cohen, J. (1998). Statistical power analysis for the behavioral sciences, New York, Lawrence Erlbaum Associates.

3. Chang, C.L., \& Luh, D.B. (2012). User as designer: A design model of user creativity platforms. Journal of Integrated Design and Process Science, 16(4), 19-30. doi: https://doi.org/10.3233/jid-2012-0020

4. Worley, C.G., Williams, T.D., \& Lawler III, E.E. (2014). The agility factor: Building adaptable organizations for superior performance. John Wiley \& Sons.

5. Grubor, A., Milićević, N., \& Đokić N. (2018). Dostupnost proizvoda u kontekstu kvaliteta usluge maloprodavca. Anali Ekonomskog fakulteta u Subotici, 39, 75-88. doi: https://doi.org/10.5937/AnEkSub1839075G

6. Jelić, M. (2016). Liderstvo - ključni činilac u modelima izvrsnosti i novom standardu ISO 9001:2015. Kvalitet $i$ izvrsnost, 5(1-2), 7-8.

7. Končar, J., Grubor A., Marić, R., Vukmirović, G., \& Đokić, N. (2019). Possibilities to improve the image of food and organic products on the AP Vojvodina market by introducing a regional quality label. Food and Feed Research, 46(1), 111-123. doi: https://doi.org/10.5937/FFR1901111K

8. Kotler, P., Vong, V., Sonders, D., \& Armstrong, G. (2007). Principi marketinga. Mate, Beograd [in English: Kotler, P., Vong, V., Sonders, D., \& Armstrong, G. (2007). Principles of marketing. Mate, Belgrade].

9. Kokeza, G. (2016). Uloga inovacija menadžmenta u inovativnoj i kreativnoj ekonomiji. Ekonomski vidici, 21(2-3). 145-157. 
10. Maričić, B., \& Đorđević, A. (2015). Creating and delivering value to customers. Faculty of Economics, Belgrade. [In Serbian: Kreiranje i isporučivanje vrednosti potrošačima. Ekonomski fakultet, Beograd].

11. Marković, M., Krstić, B., \& Rađenović, Ž. (2019). Export competitiveness of the Serbian agri-food sector on the EU market. Economics of Agriculture, 66(4), 941953. doi: https://doi.org/10.5937/ekoPolj1904941M

12. Miletić, V., Ćurčić, N., \& Aničić, D. (2017). Quality of Serbia Products - Sustainable Competitiveness key on Open Market. XV International multidisciplinary scientific conference „Eurobrand“, 24-26 november, TQM Centar Zrenjanin, e-Zbornik, 7385.

13. Miletić, V., Miletić, S., \& Ćurčić, N. (2018). Profitabilno poslovanje organizacije kao ishod unapređenja konkurentnosti primenom koncepta CRM. Anali Ekonomski fakulteta u Subotici, 40, 33-48. doi: https://doi.org/10.5937/AnEkSub1840033M

14. Mullins, J.W., Walker, O.C., \& Boyd, H.W. (2008). Marketing Management: A Strategic Decision-Making Approach (6th ed). New York: McGraw-Hill Irwin.

15. Namiki, M. (2011). Success ful Share-building Strategies for High -technology Companies, College of Business, Graduate School of Business Administration, Rikkyo University. Business Review, 4 , 50-52.

16. Pascu, C., \& van Lieshout, M. (2009). User-Led, Citizen Innovation at the Interface of Services. Info, 11(6), 126-128.

17. Porter, M.E. (1980). Competitive Strategy. Free Press, New York.

18. Simonović, Z., Petrović, D., \& Ćurčić, N. (2019). Production of grapes and wine in Serbia. Ekonomika, 65(4), 11-20. doi: https://doi.org/10.5937/ekonomika1904011S

19. Haavisto, P. (2014). Observing discussion forums and Product innovation - A Way to Create Consumer value? Case Heart-Rate Monitors. Technovation, 34(4), $215-$ 222. doi: https://doi.org/10.1016/j.technovation.2013.12.001

20. Vukajlović, Đ., \& Ćurčić, N. (2016). Assessement of competitiveness and innovation factor in order to achieve market share. Economics: theory and practice, 9(3), 35-54. [In Serbian: Ocena faktora konkurentnosti i inovativnosti u cilju ostvarivanja tržišnog učešća. Ekonomija: teorija i praksa, 9(3) 35-54].

21. Ćurčić, N. (2018). Business success of a modern organization. Institute of Agricultural Economics, Belgrade. [In Serbian: Poslovni uspeh savremene organizacije. Institut za ekonomiku poljoprivrede, Beograd].

22. Yeung, M., \& Ramasamy, B. (2007). Brand Value and Firm Performance Nexus: Further Empirical Evidence. Journal of Brand Management, 15(5), 322-335.

23. Walas-Trębacz, J. (2018). Efficiency evaluation of the functioning of an enterprise's value chain as a criterion for the choice of a successful strategy of market comprtition. Ekonomika, 64(2), 9-22. doi: https://doi.org/10.5937/ ekonomika1802009W 